\title{
Legal Aspects of LLL
}

\author{
Larisa G. Gotsko, \\ Svetlana A. Trofimova and Inna B. Trofimova* \\ Krasnoyarsk State Agrarian University \\ 90 Mira, Krasnoyarsk, 660049, Russia
}

Received 05.06.2015, received in revised form 15.08.2015, accepted 04.09.2015

Educational processes accompany an individual for all his life: from the prenatal period, when the expectant mothers undergo training in the medical institutions; it continues in the pre-school institutions; develops during secondary school education for all; is carried out at a higher level in the system of institutions of higher education for those capable to this process. After the university graduation and job placement education is provided in three areas: professional training, access to the second higher education through the system of government and non-government educational institutions and self-education. Legal securing of the educational process according to all these areas is of great importance. The article presents an analysis of the Federal Law "On Education in the Russian Federation", the principles and goals of each educational stage. It emphasises both the peculiarities and problems of the disable children education. The article contains the survey data of the first year students on their school knowledge awareness. The issues on lifelong learning stipulated by the Federal law "On Education" together with the problems left unregulated by the law in question are under the authors' consideration.

Keywords: Federal law "On Education in the Russian Federation”, goals and principles of education, stages of the education, Russian lifelong learning problems.

The article is written with the financial support of the European Commission within the Tempus IV programme (Project "Lifelong Language Learning University Centre Network for New Career Opportunities and Personal Development (UNICO)”, № 544283-TEMPUS-1-2013-1-ES-TEMPUSJPHES).

DOI: $10.17516 / 1997-1370-2015-8-11-2307-2315$

Research area: pedagogy.

Introduction. The new millennium was marked by radical changes in the European educational space, caused by the 2000 Lisbon strategy adopted by the European Council. Creating a Europe of knowledge has become a major challenge for the European Union.
The "lifelong learning" (L.L.L.) concept has appeared.

The Russian federal law "On Education in the Russian Federation" (further the law) passed in December 2012 created a legal basis for this concept adaptation to the Russian reality.

(C) Siberian Federal University. All rights reserved

* Corresponding author E-mail address: larissa_gotsko@mail.ru 
We consider the issues of the legal regulation of LLL certain matters which are stipulated by the law together with those left unregulated by it.

Discussion caused by the law passage. Different state officials and researchers fail to come to one opinion concerning the education goals issues. If the Defense Minister Sergei Shoigu considers that there are new challenges which should be met by today school, namely they are to reveal abilities of every schoolchild, to develop scientific way of thinking, to form an active social position, to educate true patriots of our homeland then the former head of the Ministry of Education stated that the main task of education is to bring up a qualified consumer. The present Minister did not make a rebuttal.

The law provides for the separate categories of the individuals possibilities to implement some kinds of programmes and to obtain education. It concerns those with outstanding abilities; foreign citizens, stateless persons; persons with disabilities; persons convicted to imprisonment, and others.

It sets forth the forms of education and scientific research activities integration into higher education. Article 3 of the Law stipulates the basic principles of legal regulation in the sphere of education.

The Law prescribes inadmissibility of discrimination in the sphere of education, the priority of human life and health, human rights and freedoms, protection and development of ethnic and cultural features as well as traditions of the peoples of the Russian Federation, the secular nature of public education, the inadmissibility of restrictions or establishing competition in the field of education, and others.

Article 3 of the Law sets forth the basic principles of legal regulation in the sphere of education. Inadmissibility of discrimination in the sphere of education, the priority of life and health, human rights and freedoms, protection and development of ethnic and cultural features and traditions of the Russian Federation peoples, the secular nature of public education, the inadmissibility of restrictions or competition in the field of education, and others. The provision of item 8 , article 3 of the Law proclaiming the right to long life education guarantee in accordance with the needs of every individual, adaptiveness of the education system to the level of training, peculiarities of development, abilities and interests of an individual is the most valuable for us.

It stipulates the rights of a student together with the opportunities to acquire the main study programmes in the form of self-education or family education, followed by the external free interim or state final certification in the educational establishment on a given study programme.

It is impossible to accomplish educational activity without the pedagogical employee's involvement.

Article 47 of the Law defines the legal status of a pedagogical employee as the aggregate of rights and freedoms, labour rights, social guarantees and compensations, restrictions, obligations and responsibilities established by the legislation. Freedom of teaching freedom of expression, and freedom of interference in professional activities are referred to academic rights and freedoms. It secures the right to creativity, to the choice of textbooks and teaching aids, to scientific artistic, and research activities, the right to protection of professional honor and dignity to name a few.

A special question arises concerning the right to textbooks choice implementation taking into account the fact that the ministry of education strongly recommends to use books from the recommended list.

It is the recommended passed the expert examination textbooks though, that contain factual, grammatical and semantic errors and 
even some inhuman statements conducive to create wrong attitudes towards the disable, etc.

The Law prescribes several education stages:

- pre-school education (article 64)

- primary general, basic general and secondary general education (article 66)

- secondary vocational education(article 68)

- higher education (article 69)

- supplementary education (articles 75, 76)

The objectives of each level of education are defined in the corresponding articles of the Federal Law «On Education». Thus, article 64 of the law stipulates the goals of preschool education where the most important once are: culture formation, physical, moral, intellectual, and personal qualities development.

It is in this period when the formation of preconditions of educational activity is being created. Children should achieve the level of development sufficient for the successful learning of the primary general study programmes.

Primary general education suggests that the child mastered reading, writing, numeracy, basic skills of training activities and elements of theoretical thinking. The Law does not require for a child to obtain all these skills at the ten's grade admission.

However, the formation of a schoolchild's personality, their moral beliefs, aesthetic taste, culture of interpersonal and inter aesthetic education, mental and physical labor skills as well as the inclinations to social selfdetermination are created during the basic general study programmes learning (part 2, article 66).

There is a clear contradiction between the two articles of the law: Art. 34 prohibits the involvement of students without their consent, and the minors without their parents consent to work not provided by the study programme and article 66 which stipulates that the student must have their physical labour skills formed during the learning period.

Mainly, formation of the latter is still carried out within the family. A child's help his grandmother to weed vegetable patches in the village, to look after domestic animals turns out to be the very development of his manual labor skills.

Unfortunately, an increasing number of children do not even know the word «village». All their labour skills are limited by washing up, sweeping the floor, sometimes by the ability to iron a shirt. If they know how to cook some very basic dishes it appears to be the matter of the family friends' jealousy. When these children happen to find themselves away from home or outside the habitual circle of life, they are much more difficult to adapt to new conditions. Even living in a university dormitory equals to stress for them. This inability caused by the lack of labour skills might be one of the reasons for lower mobility of our school leavers when choosing a university, compared with the mobility of the students in Europe and the United States.

Education is deemed the process of the world around image formation. In philosophy an image is the result of the reflection of an object in a man's consciousness by means of senses, perceptions and ideas on a sensory level of its cognition up to the formation of a concept, judgment and inferences at the level of thinking. Practical actions are subject to image embodiment. Once appeared an image takes on a relatively independent character and plays an active role in the effective behavior of a man, performs the functions of their actions governing.

The image formation of the world around starts in the prenatal period, and if we take into consideration the concept of inheritance of social experience of previous generations - even earlier. 
In the pre-school period the education process is carried out within the family and in kindergartens. Different elements of the education system existing in a given society in a certain country are more and more involved in this process.

It is common knowledge that the state system of preschool institutions establishment was caused by the need to involve women in social production although the ideas of public education appeared in Plato's ideal state two thousand years ago.

Psychologists and teachers periodically argue over the proper age for a child to attend kindergarten. On the one hand, team skills are formed in a kindergarten while on the other hand «home» children's nervous system is proved more stable, etc.

According to article 67 of the Law preschool education in the educational organization is available to children at the age of two months. In Soviet times, such organisations were called nurseries and have been widely established that enables parents to return to their jobs as soon as possible. In the post-perestroika period, this type of organization was practically ceased to exist. The system of maternity leaves duration of which became rather long was also an advantage.

In many areas of the country the local authorities taking into account the shortage of pre-school institutions capacity make a decision to pay a family a certain sum of money in return for a child's non attendance of a kindergarten.

If it is admitted for a pre-school educational process to be carried out within a family in a private or public kindergarten then the school educational process begins for a child aged $6-7$. It should be noted that home education is possible within this period as well subject to the certain requirements for the family to meet for a child to be awarded a school leaving certificate.
It should be emphasized that the law defines more flexible entry age for a child admitted in school: under the general rule this age should correspond to six years and six months, but not older than eight. At the same time the founder of the educational organization is entitled to admit the younger or older children at the request of their parents.

The majority of families cannot afford education at home, and the process of the world around image formation is transferred to school and teachers sphere of competence. The latter shall carry out the educational process in compliance with the state educational standard.

Fortunately, the authors left school prior to the age of its absolute domination. We went to different schools, but we tidied classrooms ourselves, did extra curriculum and voluntary social work, collected scrap metal and waste paper, helped veterans, staged literary performances, arranged historical tournaments and debates, tried to get thoroughly prepared in a library to demonstrate perfect awareness of the subject at the school classes. There was no Internet that time but there was another advantage we were able to have the opinion of our own as we did not worry about the dilemma which answer the author of the examination texts considers the only correct one. Neither did our parents.

A year or two before their children go to school modern parents are consciously and unconsciously made anxious about the only thing: which school is the best for their child to attend and what measures to undertake to be admitted in it. The top criteria to take into account are the matters of prestige, status and so forth.

On the one hand admission regulations according the basic study programmes are designed to ensure all citizens entitled to the general education of a corresponding level. On the other hand, the law specifies that the state and municipal educational institutions should ensure 
admission of citizens residing in the territory allotted to the organization.

The law prescribing such rules in items 2 and 3 of article 67 gives parents the opportunity to choose a school. In its turn, the school is given an opportunity to admit children who reside outside the territory allotted to the educational organization.

Actually, very few people think about a child's comfort at such a school. All the more, nobody wonders what image of the world around a child will have created when leaving school. Will the interest in cognitive activity or ideas, concepts, judgments remain at the level of everyday knowledge, based on common sense and ordinary consciousness?

Ideally, it is in the school period when the transition from everyday knowledge to scientific one characterized by the facts comprehension, generalization, where a random thing is accompanied by a necessary and naturally determined one, a single and private thing is accompanied by the general one should start. It is on this basis prediction is performed: from superficial to the deeper, more essential and comprehensive knowledge which serves a prerequisite for transforming human activities.

What knowledge do our children acquire when leaving school? We conducted a survey of the first and third year students to find out what general information about the world, the country, our region they have left after leaving school and how they have changed over a 2 year period of the University studies. The students were asked to name five capitals of the states, five capitals of the territories and regions of the Russian Federation; five poets, writers, historic personalities of the world, Russia; five countries which border Russia today; five Krasnoyarsk places of interest; five names of well-known Krasnoyarsk - born Siberians; the purpose of university admission; the latest book read.
The first year students made a few mistakes. They referred Saint - Petersburg and New York to capitals. Kalmykia, Tatarstan, Tuva, Africa, America were referred to foreign states. The third year students have not made such mistakes.

All respondents mentioned the names of writers and poets known from the school curriculum.

V. Surikov and D. Khvorostovsky are the two names of the well known Krasnoyarsk-born citizens have been most often mentioned. Some students recalled another famous Krasnoyarsk born writer - V. Astafev. All respondents referred the Reserve "Pillars", the Park of Flora and Fauna "Swarms brook", Surikov's house-museum, theaters, squares to places of interest.

As to the books read the most frequently mentioned ones were "A Song of Ice and Fire", "Blood and Iron", "Fifty shades of grey". Russian authors' books especially modern ones' have not been recalled except for monographs on the syllabus discipline.

It can be concluded that a clearer conception both about Russia and the world are formed by the third year of studies. There are no more mistakes in terms of the names of the capitals, countries and the Russian Federation entities. There are things to think over the educational work implementation. The inclination should be aimed at compiling knowledge about well-known fellow-townsmen, places of interest which are the matter of all Krasnoyarsk residents' pride.

Goals for the University admission are as follows: a diploma, higher education knowledge and a well- paid job after graduation.

Variants of answers: graduation was referred only twice, networking was mentioned only ones. Some respondents consider higher education a condition for further self development.

To find out to what extend "qualified consumers" are formed in higher school, 
we have included three questions on this matter and asked to name the five automobile modes, clothing brands, five currencies. $4 \%$ of first-year students failed to answer these questions. The rest of the first-year students, and all third-year students easily named the companies, brands, trademarks and currencies, demonstrating that they are ready for qualified consumption. Unfortunately, the Russian names have not entered the produced list.

"Unteachable" students. Insufficient level of knowledge acquired at school leads to university education quality decrease which is one of the most pressing problems of Russian higher education. According to researchers a new category of "unteachable" students incapable to cope with the syllabuses, but are in favor of the universities owing to their sports achievements, and other out of class activities. The category in question has been studied thorough enough by the researcher from the Far Eastern universities, namely by E.V. DenisovaSchmidt and E. O. Leontieva (DenisovaSchmidt \& Leontieva, 2015). According to Krasnoyarsk universities lecturers the given category of students is increasing every other year.

The Federal law "On education" giving universities an opportunity to provide educational services on a commercial basis suggests that they should solve a peculiar dilemma: to build up a financial base by means of increasing the number of students paying tuition fee. However, but as experience shows these school leavers tend to have low average score of their State exam; but requires to introduce a quality management system of education, which demands additional administrative staff and financial costs to monitor its implementation. The issue on real quality of education increase remains open - ended.
At the same time the law "On education in the Russian Federation" sets forth the goal of educational and research activities integration into higher education to provide the research with the staff, to involve students in scientific research, to use new knowledge and achievements in science and technology in educational activities. Research education should become the main form of school and university training. S.A. Karpov (Karpov, 2015) suggests forming certain groups of young people who prove to be promising in terms of working with state-of-the-art knowledge. From his point of view, research training arrangement assumes:

- Development of specific research syllabuses on profiled disciplines;

- Formation of a group of promising students ;

- Provision of research work with material and technical base;

- Inclusion of coherent syllabus of research education into a curriculum of different stages of secondary and higher education.

We share V. Sadovnichy's opinion who considers that it is the support of training specialists capable of creating that will save the education system.

The problem of disable children education. Another problem which solution is getting more and complicated is the organization of education of students with disabilities. Officially, the law "On education" provides such opportunities, but dozens of specialized educational institutions have been annually closed down recently (from 2004 to 2012). Their number decreased by 229 units (Kulagina, 2015). The attempts to introduce inclusive education in secondary schools sometimes cause resistance on the part of the rest of the schoolchildren's parents. The school teachers are often not prepared for teaching such children. 
One of the reasons is the unresolved issue of financing and teaching such children at school.

General secondary education is aimed at development of a pupil's interest in knowledge and creative abilities development, preparation for independent life choice, continuing education, professional activity beginning (part 3 , article 66).

The listed stages of education are mandatory. If the primary, basic general, secondary general are not acquired a person is not allowed to study at the following levels.

The goal of the secondary vocational education is to train skilled workers, employees, mid-level professionals in all areas of the activity (article 68).

The goal of higher education is training of highly qualified personnel in all areas of socially useful activity.

The problem of supplementary and further after higher school education is the subject of thorough consideration. It is implemented by means of the institutions and training courses paid by the employer; distance education when a person undergoes a second higher education they need to do their work, but there are devotees of learning (those who collect diplomas). A student currently doing his tuition by correspondence at our University and having already obtained three diplomas can serve a good example of the said above. He is still in search of a proper qualification for him.

Self-education outside the formal educational institutions lasts for life for the majority of the Russian people.

If we manage to cultivate and develop a taste for self-education, creativity by means of conferences, business games and other scientific research forms of activity, we can admit our mission accomplished.

Specific methods of the Far North indigenous peoples' children education. The implementation of lifelong learning concept not only provides for new opportunities, but updates a lot of problems either. One of these problems is the communities of such population groups who lead a traditional way of life activity. The indigenous peoples of the Far North living in Russia and northern Europe regions refer to this group. They lead a nomadic life style. The Soviet period authorities' policy towards the indigenous peoples changed repeatedly. Over thirties and forties years of the 20th century during the illiteracy liquidation period "the red tent" (a traditional made of skins dwelling of indigenous peoples adapted for practicing) moved together with reindeer breeders roaming together with the reindeers from place to place across the tundra. A teacher travelled with reindeer breeders. $\mathrm{He}$ conducted classes teaching reading and writing imparted elementary knowledge on the world outside the tundra.

In essence, it was a brief primary education. Such an approach played its positive role in the course of illiteracy liquidation and inspired many representatives of indigenous peoples with the need for knowledge which they implemented in technical secondary schools and institutes. The Institute of indigenous North peoples was set up in Leningrad where plenty of indigenous peoples used not to have written language have acquired one. This process was interrupted by World War II.

Within the postwar period the policy in the educational sphere changed. Indigenous peoples' children were taken away from their families and placed in boarding schools, located in the centers of the autonomous regions, hundreds of kilometers away from their parents within the airplane flight distance. As a result children grew up not adapted to a traditional mode of life. At the same time, few of them tended to adjust to live "on the continent". These days the territory on the North which is 
situated 70 parallel to the south is still called "the continent".

In the Magadan territory the same refers to Russia situated westwards Magadan city (Ivanova \& Kuteinikov, 2015) mainly its European part. The issues of indigenous peoples' traditional lifestyle are highlighted in more detail in the monograph "Social philosophical analysis of civil society development diversity and indigenous peoples of the Far North integration into it" by S.A.Trofimova (Trofimova, 2006).

The modern state used to refuse the attempts to transfer indigenous peoples to a settled life style and to keep reindeers in enclosures (the 20th century early $80^{\text {th }}$ failed experiment), to take young children of pre-school age away from their families and to place them in a boarding school. The traditions of "red tents" were renewed serving a kindergarten for preschool children and primary school for the children of school age. Owing to this they retain links with their family, acquire skills of traditional mode of life. Later when they obtain general secondary education, indigenous peoples' children can make a more conscious choice, namely what lifestyle to prefer: whether traditional, nomadic or settled whether in settlements or cities.

Today, in the period of heightened attention to the Arctic region, the implementation of lifelong learning for indigenous peoples can play its positive role in the further development of the
Arctic. Especially, if we take into consideration migration mobility and the fact that it does not take long for representatives of the indigenous peoples to adapt to the extreme conditions of life in the Far North: these conditions are ordinary for them at the genetic level, while $69 \%$ of newcomers would like to live in other regions.

All the more it is not clear why the Federal Law "On Education in the Russian Federation" failed to mention such category of the population as indigenous peoples but payed special attention to those imprisoned.

The law fails to pay due attention to research to joint international research. The potential of participation strategy in international collaboration is underused that prevents from getting a synergy effect of several educational systems simultaneous work. Our law has evaded these opportunities with science. The Netherland's experience should be adopted in terms of selecting several focus centres on international cooperation and internationalisation in education which would be engaged in advising prospective students, assisting in dealing with organisational matters, supporting the alumni liaisons with each other and with cultural and business environment in Russia. Such a relationship would facilitate the citation increase as well. To sum up, the issues on lifelong learning stipulated by the Federal law "On Education in the Russian Federation" together with the problems left unregulated by the law need both further thorough consideration and regulation.

\section{References}

Denisova-Schmidt, E.V. \& Leontieva, E.O. (2015). The category "unteacable" students as a social university phenomenon. Sociological research, (9), 86-93.

Ivanova, N.A. \& Kuteinikov, A.E. (2015). Migration from Magadan region. Sotsis, (9), 80-85.

Karpov, A.O. (2015). Education for social sciences: genesis and social challenges. Sociological research, (5), 86-98.

Kulagina, U.V. (2015). Education of disabled children and children with disabilities: trends and regulatory criteria. Sotsis, (9), 94-101. 
Trtofimova, S.A. Social philosophical analysis of civil society development diversity and indigenous peoples of the Far North integration into it. Krasnoyarsk State Agrarian University, 2006, p. 12-13.

\title{
Правовые аспекты образования
}

\section{в течение жизни}

\author{
Л.Г. Гоцко, \\ С.А. Трофимова, И.Б. Трофимова \\ Красноярский государственный аграрный университет \\ Россия, 660049, Красноярск, пр. Мира, 90
}

\begin{abstract}
Образовательные прочессы сопровождают человека всю жизнь: от пренатального периода, когда осуществляется обучение будущих мам в системе медиииских учреждений; продолжается в системе дошкольных учреждений; развивается в период обучения в школе для всех; осуществляется на более высоком уровне в системе высших учебных заведений для лии, способных к данному прочессу.

После окончания вуза и трудоустройства образование осуществляется по трем направлениям: повышение профессиональной квалификации, возможности получения второго образования через систему государственных и негосударственных учебных заведений и самообразования. По всем этим направлениям важную роль играет правовое обеспечение образовательного проиесса.

Статья представляет анализ Федерального закона «Об образовании в Российской Федерации», принципы и цели каждой стадии образования. Рассматриваются особенности и проблемы образования детей с ограниченными возможностями. Статья содержит данные опроса студентов первого курса относительно объема их школьных знаний. Кроме того, исследуются оставшиеся неурегулированными в законе вопросы образования в течение всей жизни.

Ключевые слова: Федеральный закон «Об образовании в Российской Федерации», иели и принципы образования, стадии образования, проблемы непрерывного образования в России.

Статья написана при финансовой поддержке гранта программы ТЕМПУС IV Европейского Союза (проект «Создание сети университетских языковых иеетров для профессионального и личностного развития человека в рамках парадигмы «образование в течение всей жизни», № 544283-TEMPUS-1-2013-1-ES-TEMPUS-JPHES).
\end{abstract}

Научная спечиальность: 13.00.00 - педагогические науки. 